Original

Article

\section{Use of simple hematological, biochemical and clinical parameters to monitor response of multiple myeloma patients on high dose thalidomide therapy}

\author{
Uppal G, Raina $\mathbf{V}^{\star}$, Sharma $A^{\star}$, Anand $\mathbf{M}^{\star \star}$, Kumar $\mathbf{R}^{\star \star}$, Khaitan $\mathrm{BK}^{\star \star \star}$, Grover JK \\ Departments of Pharmacology, ${ }^{*}$ Medical Oncology, ${ }^{* *}$ Laboratory Oncology, Institute Rotary Cancer \\ Hospital, ${ }^{\star \star \star}$ Dermatology, All India Institute of Medical Sciences, New Delhi - 110029, India \\ Correspondence to: Dr. Vinod Raina, E-mail: vinodraina@hotmail.com
}

\title{
Abstract
}

BACKGROUND: Evidence of increased bone marrow vascularity in multiple myeloma (MM) has led to the use of anti-angiogenic drugs especially thalidomide in relapsed or refractory patients. Currently, parameters such as serum/ urine electrophoresis for $\mathrm{M}$ (monoclonal) proteins, bone marrow biopsy with touch preparation and $\mathrm{b}_{2}$ microglobulin are routinely used to assess response to therapy. These investigations are expensive, invasive and require high technical setup. AIM: To correlate simple and routine hematological and biochemical parameters with the key marker of disease i.e. M proteins. SETTINGS AND DESIGN: This is an open label, uncontrolled, single-arm study. MATERIALS AND METHODS: Twenty nine refractory or relapsed multiple myeloma patients of both sexes ( $M=20$, $\mathrm{F}=9$ ) with age ranging between 35-72 years were initiated on $200 \mathrm{mg} /$ day of thalidomide with fortnightly increments of $200 \mathrm{mg}$ to a maximum tolerated dose not exceeding $800 \mathrm{mg} /$ day. All hematological and biochemical parameters were monitored at monthly intervals for one year. STATISTICAL ANALYSIS: Correlation analysis was performed between hemoglobin $(\mathrm{Hb})$, total leukocyte count (TLC), absolute neutrophil count (ANC), platelet count (PC), total proteins (TP), serum albumin and serum globulin on one hand and $\mathrm{M}$ protein levels on the other using Pearsons Correlation test by SPSS version 7.5. RESULT: Hb, TLC, ANC, PC and serum albumin levels showed a significant negative correlation with $\mathrm{M}$ proteins. A highly significant positive correlation existed between $\mathrm{M}$ proteins on one hand and TP and globulin levels on the other. Dryness of skin indicated positive response to therapy. These correlations were found to be significant at the end of one month of therapy in all the above-mentioned parameters except in TLC where it was significant after 2 months of thalidomide therapy. CONCLUSION: Results suggest that sustained efficacy of thalidomide therapy may be amenable to monitoring by these simple, inexpensive and easily available investigations after ascertaining an initial response by $\mathrm{M}$ protein and marrow plasmacytosis as these parameters closely follow $\mathrm{M}$ protein levels. However more studies are required to further substantiate these findings.

Key Words: Multiple Myeloma, thalidomide, parameters for assessment of response

\section{Introduction}

Multiple myeloma is a part of a broad spectrum of plasma cell disorders, which include monoclonal gammopathy of undetermined significance (MGUS), smoldering multiple myeloma (SMM) and solitary plasmacytoma. It accounts for $1 \%$ of all malignancies \& $10 \%$ of malignant hematological neoplasms. ${ }^{[1,2]}$ It is characterized by the presence of a monoclonal $(\mathrm{M})$ protein in serum or urine, osteolytic bone lesions, 
increased plasma cells in bone marrow, anemia and hypercalcemia. ${ }^{[1]}$ With identification of angiogenesis as a key pathophysiological process important in growth, local invasiveness and metastases of malignant tumors the use of anti-angiogenic agents has gained importance. ${ }^{[3]}$ Increased angiogenesis has also been demonstrated in MM. ${ }^{[4,5]}$ The use of anti-angiogenic agent thalidomide in the treatment of relapsed/refractory MM has shown a high overall response rate in the range of $25-64 \%$ in different trials. ${ }^{[6-14]}$ This agent after almost a gap of 20 years has emerged as an effective new modality of MM treatment with minimal adverse effects.

Bone marrow suppression, as compared to conventional cytotoxic drugs, has not been observed with thalidomide due to its different mechanism of action. In assessment of response to conventional therapy various parameters such as serum/urine electrophoreses, bone marrow biopsy with touch preparation and $b_{2}$ microglobulin are used. Most of these investigations are costly, invasive and require high technical set up. Hematological and biochemical profile of the patients is done as a part of routine investigations along with the above investigations. We attempted to correlate these hematological and biochemical parameters with $M$ proteins so as to find simple, easily available and cheap alternative parameters for monitoring response to thalidomide therapy. These parameters are part of routine investigations being carried out even at peripheral centers. Secondly, their use for monitoring response will decrease the frequency of currently used expensive investigations. However, these assessment criteria are useful only in context of new anti-angiogenic modalities with minimal side effect profile like thalidomide and not for conventional chemotherapy.

\section{Material and Methods}

Twenty nine multiple myeloma patients of both sexes $(\mathrm{M}=20, \mathrm{~F}=9)$ with age ranging between $35-72$ years were enrolled in the open-labeled, single-arm study after taking approval from Institute Ethics Committee. Thalidomide was supplied (Thalidomid ${ }^{\mathrm{TM}}$ 100) as 100 mg tablets by Grunenthal GmbH, Germany on an individual patient basis. An informed consent (according to WHO guidelines and in accordance with the format provided by Grunenthal laboratory, Germany) was obtained from the patients before initiating therapy.

Inclusion criteria included patients with refractory (nonresponders to chemotherapy) relapsed (initial responders to chemotherapy but subsequent progressive disease) multiple myeloma. Patients with liver enzyme levels more than twice the upper limit of normal (SGOT and SGPT $>100 \mathrm{IU})$ at time of inclusion or patients on thalidomide therapy prior to the trial or with any coexisting life threatening condition were excluded from the trial.

Pregnancy test was done in all females in reproductive age group before starting therapy and also patients were advised to use double contraceptive measures during the course of treatment.

Hemogram, blood chemistry, serum or urine $M$ protein levels, bone marrow biopsy and touch preparation and skeletal survey with clinical assessment were done at the start of trial. Thereafter hemogram, blood chemistry, $M$ protein levels and clinical assessment were done at monthly intervals whereas bone marrow biopsy and skeletal X-rays were done at 3 monthly intervals.

Dosage schedule for thalidomide as described by Singhal et al was followed ${ }^{[7]}$ and the patients were initiated on $200 \mathrm{mg} /$ day of thalidomide with fortnightly increments of $200 \mathrm{mg}$ to a maximum tolerated dose not exceeding $800 \mathrm{mg} /$ day. Patients were assessed for 12 months of therapy. The median duration of daily thalidomide administration was 8 months.

\section{Statistical analysis}

Pearsons Correlation Analysis was used for analyzing results for statistical significance by SPSS version 7.5.

\section{Results}

A total of 29 patients were included in the present trial. Information and follow-up was available on 26 patients. Of the 26 patients enrolled in the trial 17 had relapsed after conventional chemotherapy (15 patients had $>1$ regimen of chemotherapy, 7 patients were enrolled into the trial post peripheral blood stem cell transplant) and 9 patients were refractory to conventional chemotherapy. On an average 7 months had elapsed between start of thalidomide and the last cytotoxic therapy (range is 412 months). In none of the patients was thalidomide administered as maintenance therapy. The median duration for which thalidomide was administered was 8 months and $600 \mathrm{mg} /$ day was the most common maximum tolerated dose by the patients.

Baseline investigations of the patients are given in Table 1. Patients were closely monitored over a period of 1 year. The patients reported subjective improvement in their general condition within 6 weeks - 2 months of therapy. Response criteria were used according to guidelines of the EBMT/IBMTR (European/ 
Table 1: Baseline parameters of the patients

\begin{tabular}{lll}
\hline Parameter & Median & Range \\
\hline Hemoglobin $(\mathrm{g} / \mathrm{dl})$ & 10.9 & $8-14.1$ \\
\hline TLC $\left(10^{3} / \mathrm{cmm}\right)$ & 5450 & $1700-12600$ \\
\hline Platelets $\left(10^{3} / \mathrm{cumm}\right)$ & 178 & $(63-346) \times 10^{3}$ \\
\hline ESR $(\mathrm{mm} / \mathrm{hr})$ & 47.5 & $(10-110) \mathrm{mm}$ \\
\hline Creatinine $(\mathrm{mg} \%)$ & 1.1 & $0.5-1.7$ \\
\hline Calcium $(\mathrm{mg} \%)$ & 9.7 & $(8.2-11.9)$ \\
\hline Uric acid $(\mathrm{mg} \%)$ & 4.85 & $2.5-8.4$ \\
\hline S. proteins $(\mathrm{g} / \mathrm{dl})$ & 7.95 & $6.6-10.5$ \\
\hline Albumin $(\mathrm{g} / \mathrm{dl})$ & 4.25 & $3.3-5.1$ \\
\hline S. globulin $(\mathrm{g} / \mathrm{dl})$ & 3.55 & $2-7.1$ \\
\hline Alk. Phosphatase $(\mathrm{IU} / \mathrm{ml})$ & 151 & $70-928$ \\
\hline SGOT $(\mathrm{U} / \mathrm{ml})$ & 27.5 & $13-77$ \\
\hline SGPT $(\mathrm{U} / \mathrm{ml})$ & 19 & $6-88$ \\
\hline ANC $\left(10^{3} / \mathrm{cmm}\right)$ & 3.25 & $1-9.4$ \\
\hline M proteins $(\mathrm{g} / \mathrm{dl})$ & 1.65 & $0.9-3.6$ \\
\hline Marrow plasma cells & $25-30 \%$ & $2-65 \%$ \\
\hline
\end{tabular}

International Bone Marrow Transplantation Registry).[15] Out of 26 patients included in the analysis, 16 patients $(61.53 \%)$ showed positive response to therapy characterized by at least $25-50 \%$ decline in serum and/ or urine $\mathrm{M}$ proteins. Response to treatment is given in Table 2.

The most common adverse effects reported in the trial were constipation and sedation with an incidence of $100 \%$ and $88 \%$ respectively. Both adverse effects were noticed at $200 \mathrm{mg} /$ day dose level and were not dose dependent. No increase in severity was seen with in dose of thalidomide. Other important side effects reported were ankle edema, dry skin and peripheral neuropathy. Detailed side effect profile observed in the

\section{Table 2: Response ${ }^{15}$ of patients to daily thalidomide therapy $(n=26)$}

\begin{tabular}{|c|c|c|}
\hline Response & No. of patients & $\%$ \\
\hline CR* (Complete Response) & 12 & 46.15 \\
\hline $\mathrm{PR}^{\dagger}$ (Partial Response) & 2 & 7.69 \\
\hline MR ${ }^{\dagger+}$ (Minimal Response) & 2 & 7.69 \\
\hline Stable disease ${ }^{\S}$ & 6 & 23.77 \\
\hline Progressive diseasell & 4 & 15.38 \\
\hline \multicolumn{3}{|c|}{$\begin{array}{l}\text { *no } \mathrm{M} \text { component in serum and urine electrophoresis and bone } \\
\text { marrow plasmacytosis }<5-10 \% \text { and if this response lasted for a } \\
\text { minimal of } 24 \text { weeks. }\end{array}$} \\
\hline \multicolumn{3}{|c|}{$\begin{array}{l}50 \% \text { reduction in the amount of } M \text { protein and/or bone marrow } \\
\text { plasmacytosis and the results were reproducible after } 4 \text { weeks. }\end{array}$} \\
\hline \multicolumn{3}{|c|}{$\begin{array}{l}+25-50 \% \text { reduction in the amount of } \mathrm{M} \text { protein and/or bone marrow } \\
\text { plasmacytosis in } 2 \text { readings taken } 4 \text { weeks apart. }\end{array}$} \\
\hline \multicolumn{3}{|c|}{$\S<25 \%$ regression or progression of disease. } \\
\hline
\end{tabular}

trial is given in Table 3 . Out of 26 patients 16 had generalised dryness of skin more marked on the extremities and in some of these patients dryness was severe enough to cause discomfort and/or mild itching. On correlation with $\mathrm{M}$ proteins all these patients showed positive response to thalidomide. Ten patients ( 6 with stable and 4 with progressive disease) did not suffer this feature. In one patient loss of dryness of skin was the initial feature at conversion from stable to progressive disease. It was also observed that the loss of skin dryness was associated with loss of response. However the study was not statistically powered to find any significant correlation between dryness of skin and response to thalidomide. Peripheral neuropathy was reported in 1 patient after 10 months and in 5 after 1 year of daily thalidomide administration. All the patients reporting peripheral neuropathy had received a total dose of more than $200 \mathrm{~g}$. Four patients were on 800 $\mathrm{mg} /$ day and 2 were on $600 \mathrm{mg} /$ day dose.

All hematological parameters improved during the course of therapy especially $\mathrm{Hb}$, TLC and PC. None of the patients showing response to thalidomide received any hematological support during the trial duration in the form of blood transfusion and/or erythropoitin administration. These parameters at monthly intervals were correlated with $\mathrm{M}$ protein levels using Pearsons correlation (a parametric test), a significant correlation was found between $M$ proteins and hematological parameters. The results showed a highly significant negative correlation between $\mathrm{M}$ protein levels on one hand and $\mathrm{Hb}(\mathrm{r}=-0.407$,

\section{Table 3: Incidence of adverse drug reactions observed at different doses of thalidomide $(n=26)$}

\begin{tabular}{lccccc}
\hline Adverse effect & \multicolumn{5}{c}{ Dose/day } \\
\cline { 2 - 7 } & $200 \mathrm{mg}$ & $\mathbf{4 0 0 \mathrm { mg }}$ & $\mathbf{6 0 0 \mathrm { mg }}$ & $\mathbf{8 0 0 \mathrm { mg }}$ & Total \\
\hline Constipation & 20 & 5 & - & 1 & 26 \\
\hline Sedation & 21 & 1 & - & 1 & 23 \\
\hline Ankle swelling & 8 & 3 & 6 & 1 & 18 \\
\hline Dry skin & 5 & 5 & 6 & 2 & 18 \\
\hline Dry mouth & 4 & 1 & 7 & 6 & 18 \\
\hline Intercurrent infections & 2 & - & 7 & 8 & 17 \\
\hline Generalized weakness & - & 1 & 9 & 4 & 14 \\
\hline Headache & 2 & 1 & 1 & 4 & 8 \\
\hline Nausea and vomiting & 4 & - & 1 & 1 & 6 \\
\hline Pruritis & - & 1 & 2 & 3 & 6 \\
\hline Skin eruptions & - & 1 & - & 3 & 4 \\
\hline Non-specific dermatitis & 2 & 1 & 1 & 1 & 5 \\
\hline Heart burn & 3 & 1 & 1 & 1 & 6 \\
\hline Tremors & 1 & - & 1 & 1 & 3 \\
\hline Peripheral neuropathy & - & - & 3 & 3 & 6 \\
\hline
\end{tabular}


Table 4: Mean (range) values of the laboratory parameters observed at different time points

\begin{tabular}{lllllllll}
$\begin{array}{l}\text { Time } \\
(\mathrm{mo})\end{array}$ & $\begin{array}{l}\mathrm{Hb} \\
(\mathrm{g} / \mathrm{dl})\end{array}$ & $\begin{array}{l}\mathrm{PC}(\mathrm{X} \\
\left.10^{3} / \mathrm{mm}^{3}\right)\end{array}$ & $\begin{array}{l}\mathrm{TLC}(\mathrm{X} \\
\left.10^{3} / \mathrm{mm}^{3}\right)\end{array}$ & $\begin{array}{l}\mathrm{ANC}(\mathrm{X} \\
\left.10^{3} / \mathrm{mm}^{3}\right)\end{array}$ & $\begin{array}{l}\mathrm{TP} \\
(\mathrm{g} / \mathrm{dl})\end{array}$ & $\begin{array}{l}\text { Albumin } \\
(\mathrm{g} / \mathrm{dl})\end{array}$ & $\begin{array}{l}\text { Globulin } \\
(\mathrm{g} / \mathrm{dl})\end{array}$ \\
\hline 0 & $10.71(8-14.1)$ & $184(70-346)$ & $5.6(1.7-12.6)$ & $3.4(1-9.4)$ & $8.2(6.6-10.5)$ & $4.2(3.4-5.1)$ & $4(2-7.1)$ \\
\hline 1 & $10.96(7.3-14.8)$ & $201(82-490)$ & $6.4(3-11)$ & $3.8(1.8-6.7)$ & $7.8(5.9-11)$ & $4(3.1-4.8)$ & $3.8(2.3-7.8)$ & $1.71(0-3.5)$ \\
\hline 2 & $11.13(7.7-15.7)$ & $195(63-362)$ & $6.8(1.5-25)$ & $3.4(0.7-8)$ & $7.6(6.2-10.4)$ & $3.9(2.6-4.5)$ & $3.7(1.8-7.6)$ & $1.49(0-3.5)$ \\
\hline 3 & $11.15(8.2-13.7)$ & $206(60-370)$ & $4.8(1.1-9.1)$ & $3.1(1.0-7.5)$ & $7.7(4.9-9.7)$ & $4.0(2.8-5.4)$ & $3.7(1.8-6.9)$ & $1.21(0-3.1)$ \\
\hline 4 & $11.07(8.2-13.8)$ & $219(79-415)$ & $5.0(2-13.3)$ & $3.0(1.1-9.2)$ & $7.9(4.9-10.5)$ & $3.8(2.9-4.7)$ & $4(1.8-7.2)$ & $1.24(0-3.0)$ \\
\hline 5 & $11.54(6.6-14.6)$ & $227(78-399)$ & $4.8(2.6-8.8)$ & $2.7(1.5-5)$ & $8.0(5.1-10.7)$ & $3.9(2.6-4.9)$ & $4.1(2-6.4)$ & $1.18(0-3.0)$ \\
\hline 6 & $12.15(9-15.5)$ & $201(93-469)$ & $5.3(1.8-10.5)$ & $3.1(1.0-7.3)$ & $7.4(3.9-9.6)$ & $3.7(3-4.9)$ & $3.7(1.5-6.6)$ & $0.87(0-2.4)$ \\
\hline 7 & $11.95(9.5-14.6)$ & $200(51-403)$ & $4.7(2.3-9.9)$ & $2.7(0.8-6)$ & $7.6(6.1-8.8)$ & $3.9(1.9-4.6)$ & $3.7(2.8-5.2)$ & $0.89(1.2-2.4)$ \\
\hline 8 & $11.95(8.7-15.7)$ & $176(95-336)$ & $5.2(2.3-9.9)$ & $3.3(1.1-7.1)$ & $7.7(7.1-9.5)$ & $4.1(3-4.7)$ & $3.6(2.8-5.8)$ & $0.93(0-2.0)$ \\
\hline 9 & $12.42(9.7-16.4)$ & $190(61-373)$ & $5.3(2.4-10.7)$ & $3.3(1.3-7)$ & $7.8(6.9-8.7)$ & $4.2(3.8-4.8)$ & $3.6(2.3-4.8)$ & $1.15(0-3.2)$ \\
\hline 10 & $12.32(10.3-16.4)$ & $178(100-264)$ & $4.8(2.3-8.0)$ & $3.0(1.0-5.2)$ & $7.7(7.1-8.3)$ & $4.2(3.5-5.1)$ & $3.5(2.5-4.8)$ & $0.86(0-2.1)$ \\
\hline 11 & $12.17(9.3-16.4)$ & $165(80-347)$ & $4.6(2.4-9.9)$ & $2.9(0.9-6.5)$ & $7.8(7.0-8.5)$ & $4.2(3.6-4.8)$ & $3.6(2.9-4.3)$ & $1.11(0-2.9)$ \\
\hline 12 & $12.07(10.3-14.7)$ & $185(68-462)$ & $4.0(2.4-6.4)$ & $2.5(1.1-4.6)$ & $7.6(7.2-8.0)$ & $3.8(3.5-4.5)$ & $3.5(2.8-3.8)$ & $0.64(0-1.9)$ \\
\hline
\end{tabular}

$P<0.001)$, platelet count $(\mathrm{r}=-0.334, P<0.001)$, TLC $(\mathrm{r}=-0.180, P<0.009)$ and ANC $(\mathrm{r}=-0.225$, $P<0.002)$ on the other hand (Table 4 and 5 ). These parameters improved as the $M$ protein levels decreased in thalidomide recipients. The correlation was significant as early as the end of one month in case of the above parameters except TLC with which the correlation was significant at the end of two months of therapy.

Pearson's two-tailed correlation test showed a significant negative correlation between albumin levels $(\mathrm{r}=-0.408$, $P<0.001)$ and $\mathrm{M}$ proteins. A highly significant positive correlation existed between $M$ proteins and globulin levels $(\mathrm{r}=0.555, P<0.001)$, and $M$ proteins and serum total proteins (T.P) $(\mathrm{r}=0.407, P<0.001)$. (Table 5). Thus, an increase in globulin levels reflected progression in $M$ protein levels whereas an increase in albumin levels related to a decline in $M$ proteins. These correlations were found to be significant at the end of 1 month of therapy in all the above-mentioned biochemical parameters.

\section{Table 5: Correlation between ' $\mathrm{M}$ ' proteins and hematological parameters}

\begin{tabular}{lll}
\hline Pearson's correlation & $\mathrm{r}^{*}$ & $\mathrm{p}^{\dagger}$ \\
\hline 'M' proteins vs. Hb & -.407 & 0.001 \\
\hline 'M' proteins vs. platelet count & -.334 & 0.001 \\
\hline 'M' protein vs. TLC & -.180 & 0.009 \\
\hline 'M' protein vs. ANC & -.225 & 0.002 \\
\hline Total protein & -.407 & 0.001 \\
\hline Albumin & -.408 & 0.001 \\
\hline Globulin & .555 & 0.001 \\
\hline
\end{tabular}

${ }^{\star}$-regression coefficient; ${ }^{\dagger}$-probability

\section{Discussion}

Thalidomide has shown remarkable response in patients of refractory or relapsed MM. Many studies done till date have proven its efficacy as a single oral agent in treatment of relapsed/refractory MM cases. ${ }^{[7-15]}$ The high response rate observed in this study clearly indicates that thalidomide or its congeners are an important tool in the therapy of MM. The high response rate may be related to the higher dose of thalidomide administered for a longer duration (minimum 6-months daily administration) or it could be a manifestation of the limited sample size of the study. Hb, TLC, ANC, PC, T.P, serum albumin and serum globulin levels all showed an improving trend within 2 months of start of thalidomide. As no hematological support was administered to any patient showing response during trial, thus it could be concluded that the improvement in these parameters was related to response to thalidomide therapy. Therefore we attempted to correlate these simple parameters with $\mathrm{M}$ proteins. This was done so that the simple hematological, biochemical, and clinical parameters can be substituted in place of $\mathrm{M}$ protein to evaluate response to thalidomide. These investigations are easily available, cheaper and less time consuming than serum or urine electrophoresis.

A very significant negative correlation was found between $\mathrm{M}$ proteins and hematological parameters such as $\mathrm{Hb}$, TLC, ANC and PC $(P<0.01)$. This correlation was found to be significant after 1 month in all except TLC (significant correlation after 2 months of therapy).

Similarly, a significant negative correlation between albumin and $\mathrm{M}$ proteins, a positive correlation between 
total proteins and $\mathrm{M}$ proteins and globulin and $\mathrm{M}$ proteins has been seen. Thus a corresponding increase in total proteins and globulin levels and a decline in albumin levels reflect an increase in $\mathrm{M}$ proteins. Thus it can be suggested that the sustained efficacy of thalidomide therapy can be monitored by these simple parameters along with clinical assessment instead of repeated serum/urine electrophoresis. It is suggested that initially the response to drugs like thalidomide should be ascertained through $\mathrm{M}$ protein levels, marrow plasmacytosis and clinical examination and thereafter these simple parameters should be considered for the assessment of sustained efficacy of non-cytotoxic treatment modalities such as thalidomide. Also important is the fact that these simpler investigations are routinely done, even at peripheral hospitals, thus task of monitoring the patients can be made simpler, easier and cheaper. This information is of importance in the current Indian context where the sophisticated instrumentation required for repetitive high resolution serum and urine electrophoresis is not available at all centers. However simple hematological and biochemical parameters can be evaluated even at peripheral centers. Thus these simple parameters can help us monitor the disease process.

The cost of doing repetitive high resolution electrophoresis of serum along with densitometry, high resolution electrophoresis of urine and immunofixation in our institute is roughly around Rs. 1000. Whereas the cost of Complete Blood Count along with Total protein, serum albumin and globulin on an average is Rs. 100. Hence our proposed parameters are 10 times more cost effective than repetitive $M$ protein measurements.

However more studies with larger sample size are required to validate these findings. It also needs to be kept in mind that changes in these simple hematological and biochemical parameters are associated with various conditions like infection, fever, etc. However when looked at in the background of multiple myeloma, these changes are strongly associated with the disease itself. Moreover changes observed due to other conditions would not persist for this long duration. Also other conditions would be associated with their own signs and symptoms.

Thus we propose that in the changing scenario of treatment modalities for MM, simple parameters must be considered carefully to assess their status as markers for response to anti-angiogenic therapies especially thalidomide as these may prove to be sensitive end points for response to therapy.

\section{Acknowledgement}

We acknowledge Grunenthal $\mathrm{GMbH}$, Germany for supplying thalidomide for the trial.

\section{References}

1. Bataille R, Harousseau JL. Multiple myeloma. N Engl J Med 1997;336: 1657-64.

2. Greenlee RT, Hill-Harmon MB, Murray T, Michael T. Cancer Statistics. Ca Cancer J Clin 2001;51:5-36.

3. Gasparini G. The rationale and future potential of angiogenesis inhibitors in neoplasia. Drugs 1999;58:17-38.

4. Fox SB. Tumor angiogenesis and prognosis. Histpoathology 1997;30:294-301.

5. Weidner N, Semple JP, Welch WR, Folkman J. Tumor angiogenesis and metastasis- correlation in invasive breast carcinoma. $\mathrm{N}$ Engl J Med 1991;324:1-8.

6. D'Amato RJ, Loughnan MS, Flynn E, Folkman J. Thalidomide is an inhibitor of angiogenesis. USA: Proc Natl Acad Sci; 1994;91:4082-5.

7. Singhal S, Mehta J, Desikan R, Ayers D, Roberson P, Eddlemon P, et al. Antitumor activity of thalidomide in refractory multiple myeloma. N Engl J Med 1999;341:1565-71.

8. Juliusson G, Celsing F, Turesson I, Lenhoff S, Adriansson M, Malm C. Frequent good partial remissions from thalidomide including best response ever in patients with advanced refractory and relapsed myeloma. $\mathrm{Br} J$ Haematol 2000; 109:89-96.

9. Kneller A, Raanani P, Hardan IA, Levi I, Berkowicz M, et al. Therapy with thalidomide in refractory multiple myeloma - the revival of an old drug. Br J Hematol 2000; 106:391-3.

10. Rajkumar SV, Fonseca R, Dispenzieri A, Lacy MQ, Lust JA, Witzig $\mathrm{TE}$, et al. Thalidomide in the treatment of relapsed multiple myeloma. Mayo Clin Proc 2000;75:897-902.

11. Barlogie B, Desikan R, Eddlemon P, Spencer T, Zeldis J, Munshi $\mathrm{N}$, et al. Extended survival in advanced and refractory multiple myeloma after single-agent thalidomide: Identification of prognostic factors in a phase 2 study of 169 patients. Blood 2001;98:492-4.

12. Yakoub-Agha I, Attal M, Dumontet C, Delannoy V, Moreau P, Berthou $C$, et al. Thalidomide in patients with advanced multiple myeloma: A study of 83 patients-report of the Intergroupe Francophone du Myelome (IFM). Hematol J 2002;3:185-92.

13. Neben K, Moehler T, Benner A, Kraemer A, Egerer G, Ho AD, et al. Dose-dependent effect of thalidomide on overall survival in relapsed multiple myeloma. Clin Cancer Res 2002;8:3377-82.

14. Mileshkin L, Biagi JJ, Mitchell P, Underhill C, Grigg A, Bell R, et al. Multicenter phase 2 trial of thalidomide in relapsed/refractory multiple myeloma: Adverse prognostic impact of advanced age. Blood 2003; 102:69-77.

15. Blade J, Samson D, Reece D, Apperley J, Bjorkstrand B, Gahrton $G$, et al. Criteria for definition of response, relapse and progression in multiple myeloma after high-dose therapy. Br J Haematol 1998; 102:1115-23. 